\title{
Cytotoxicity of spermine oxidation products to multidrug resistant melanoma M14 ADR2 cells: Sensitization by the MDL 72527 lysosomotropic compound
}

\author{
ENZO AGOSTINELLI ${ }^{1}$, MARIA CONDELLO ${ }^{2}$, AGNESE MOLINARI $^{2}$, GIAMPIERO TEMPERA ${ }^{1}$, \\ NIKENZA VICECONTE ${ }^{1}$ and GIUSEPPE ARANCIA ${ }^{2}$ \\ ${ }^{1}$ Department of Biochemical Sciences 'A. Rossi Fanelli', Sapienza University of Rome and CNR, Biology \\ and Molecular Pathology Institutes, Piazzale Aldo Moro 5, I-00185 Rome; ${ }^{2}$ Department of Technology \\ and Health, Istituto Superiore di Sanità, Viale Regina Elena 299, I-00161 Rome, Italy
}

Received March 3, 2009; Accepted May 14, 2009

DOI: 10.3892/ijo_00000360

\begin{abstract}
It has been confirmed that multidrug resistant (MDR) human melanoma cells are more sensitive than their wild-type counterparts to $\mathrm{H}_{2} \mathrm{O}_{2}$ and aldehydes, the products of bovine serum amine oxidase (BSAO)-catalyzed oxidation of spermine. The metabolites formed by BSAO and spermine are more toxic than exogenous $\mathrm{H}_{2} \mathrm{O}_{2}$ and acrolein, even though their concentration is lower during the initial phase of incubation due to their more gradual release than the exogenous products. Both wild-type and MDR cells, after pre-treatment with MDL 72527, an inactivator of polyamine oxidase and a lysosomotropic compound, show to be sensitized
\end{abstract}

Correspondence to: Professor Enzo Agostinelli, Department of Biochemical Sciences 'A. Rossi Fanelli', Sapienza University of Rome, Piazzale Aldo Moro 5, I-00185 Rome, Italy

E-mail: enzo.agostinelli@uniroma1.it

Abbreviations: ADR2, adriamycin resistant; ALDH, aldehyde dehydrogenase; AO, amine oxidase; BSA, bovine serum albumin; BSAO, bovine serum amine oxidase; CsA, cyclosporine A; DTX, docetaxel; DOX, doxorubicin; DX, doxorubicin-resistant; FAD, flavin-adenin-dinucleotide; FBS, fetal bovine serum; FITC, fluorescein isothiocyanate conjugated; IFN $\alpha$, interferon alpha; IU, international units; LoVo, human colon adenocarcinoma; LSCM, laser scanning confocal microscopy; MAb UIC2, monoclonal antibody; MFC means fluorescence channel; MDL 72527, $\left(\mathrm{N}^{1}, \mathrm{~N}^{4}\right.$-bis(2,3-butadienyl)-1,4-butanediamine dihydrochloride; MDR, multidrug-resistant; NAD, nicotin adenin dinucleotide; ODC, ornithine decarboxylase; PBS, phosphate-buffered saline; P-gp, P-glycoprotein; PI, propidium iodide; RNAse A, ribonuclease A; ROS, reactive oxygen species; SD, standard deviation; SDS, sodium dodecyl sulphate; TEM, transmission electron microscopy; WT, wild-type

Key words: bovine serum amine oxidase, polyamines, MDL 72527 , multidrug resistance, lysosomotropic compound, melanoma cells to subsequent exposure to $\mathrm{BSAO} /$ spermine. Evidence of ultrastructural aberrations and acridine orange release from lysosomes is presented in this work that is in favor of the permeabilization of the lysosomal membrane as the major cause of sensitization by MDL 72527. Owing to its lysosomotropic effect, pre-treatment with MDL 72527 amplifies the ability of the metabolites formed from spermine by oxidative deamination to induce cell death. Since it is conceivable that combined treatment with a lysosomotropic compound and $\mathrm{BSAO} /$ spermine would be effective against tumor cells, it is of interest to search for such novel compounds, which might be promising for application in a therapeutic setting.

\section{Introduction}

It is known that polyamines are polycations required for both eukaryotic and prokaryotic cell proliferation and differentiation $(1,2)$. The naturally occurring polyamines spermine and spermidine are the biosynthetic products of putrescine, which is derived from ornithine by the action of ornithine decarboxylase (ODC), the rate-limiting enzyme $(3,4)$. If the polyamines spermine, spermidine, putrescine and related compounds accumulate excessively within cells, either due to very high extracellular amounts or due to deregulation of the systems that control polyamine homeostasis $(5,6)$, they can induce toxic effects (7). Apart from being of vital importance for the propagation and viability of most cells, the natural polyamines spermine and spermidine are also the source of cytotoxic metabolites. In fact, these molecules are substrates of a family of enzymes, the amine oxidases, that includes copper containing amine oxidases isolated from serum (8).

These enzymes are important because they contribute to the regulation of mono- and polyamine levels (9). The oxidative deamination of spermine by bovine serum amine oxidase (BSAO: EC 1.4.3.6) generates ammonia and the cytotoxic metabolites hydrogen peroxide and aldehydes $(8,10,11)$.

Hydrogen peroxide and aldehydes are able to induce stress-activated signal transduction pathways, leading to 
apoptotic and non-apoptotic cell death, in several cultured tumor cell lines (11-13). Therefore, formation of reactive oxygen species (ROS) and cytotoxic aldehydes from polyamines may have potential in cancer therapy, in analogy to other radical forming processes (14).

Moreover, it has previously been demonstrated that hydrogen peroxide and aldehydes generated by BSAO/ spermine enzymatic system were also able to overcome multidrug resistance (MDR) in human colon adenocarcinoma (LoVo) (15), and melanoma (M14) cells (11). Interestingly, both MDR cell types are more sensitive to cytotoxic spermine metabolites than their wild-type counterparts, an aspect of particular interest, since one of the problems of conventional anti-cancer therapy is the development of drug resistance.

During the past decades, considerable research has been devoted to the discovery of new and more effective pharmacological agents for clinical anti-tumor therapy, involving the polyamine pathway (16-21).

Toxic polyamine metabolites are currently explored as probable candidates for a new strategy in tumor therapy $(14,22,23)$, since it has been observed that the growth of a mouse melanoma (B16-F0) was inhibited by exposure to BSAO and spermine $(24,25)$.

Moreover, in our preliminary study it was demonstrated that the combination of BSAO/spermine with either docetaxel (DTX) or interferon alpha (IFN $\alpha$ ) had a synergistic effect on cell growth inhibition through apoptosis in both human epidermoid KB and breast cancer MCF-7 cell lines $(26,27)$. While, the induction of cell death, in colon adenocarcinoma (LoVo) and melanoma (M14) cancer cells, was potentiated by the combined treatments of $\mathrm{BSAO} /$ spermine with lysosomotropic compounds $(10,11)$.

It is known that lysosomotropic molecules, which release lysosomal enzymes (cathepsins) into the cytosol, produce oxidative stress and apoptosis (28). Therefore, the sensitization of tumor cells to anti-cancer drugs by lysosomotropic compounds, and particularly the sensitization of MDR cells, recommends scrutinizing the potential of lysosomotropic drugs in cancer therapy $(10,11,28)$.

In the present work, wild-type human melanoma cells (M14 WT), and the corresponding doxorubicin-induced MDR cells (M14 ADR2) were used to explore, in a first step, the therapeutic potential of in situ formation of cytotoxic spermine metabolites. Then, the effect of pre-treatment with $\mathrm{N}^{1}, \mathrm{~N}^{4}$-bis(2,3-butadienyl)-1,4-butanediamine dihydrochloride (MDL 72527), an inactivator of flavin-adenin-dinucleotide (FAD) dependent amine oxidase (AO), with lysosomotropic properties, on the cytotoxic effect of the spermine metabolites was investigated.

\section{Materials and methods}

Chemicals. If not stated otherwise chemicals were from Sigma Chemical Co. (St. Louis, USA). Spermine tetrahydrochloride and acroléine were from FLUKA (Buchs, Switzerland), aldehyde dehydrogenase (ALDH: EC 1.2.1.5, from yeast) and nicotine adénine dinucleotide $\left(\mathrm{NAD}^{+}\right)$from Boehringer (Mannheim, Germany). Cell culture materials were from Gibco Life Technologies Ltd. (Paisley, Scotland, UK). Doxorubicin was from Pharmacia \& Upjohn (Milan, Italy). MDL 72527 was synthesised as previously described (29).

Purification of BSAO. BSAO was purified to homogeneity essentially as described by Turini et al (30) with additional ion exchange chromatographic steps as described previously (31). The purified enzyme moved as a single band on sodium dodecyl sulphate (SDS)/PAGE and all samples employed had a minimum specific benzylamine oxidase activity of $0.38 \mathrm{IU} / \mathrm{mg}$, with International Unit (IU) defined as $\mu$ moles of substrate oxidized per min, assayed spectrophotometrically at $25^{\circ} \mathrm{C}$ by monitoring the formation of benzaldehyde at $250 \mathrm{~nm}$ absorbance $\left(\varepsilon=12,500 \mathrm{M}^{-1} \cdot \mathrm{cm}^{-1}\right)$. The protein concentration was determined spectrophotometrically at $280 \mathrm{~nm}$, assuming an absorption coefficient of $1.74 \mathrm{l} \mathrm{g}^{-1} . \mathrm{cm}^{-1}$.

Cells and culture conditions. The parental human M14 cell line, isolated from an epidermal melanoma, and the corresponding MDR variant M14 ADR2 were used in the present investigation. The resistant cell line M14 ADR2 was obtained by us culturing the M14 ADR cell line, previously selected by Molinari et al (32), in medium containing $10 \mu \mathrm{M}$ doxorubicin (DOX) for several passages. Both resistant lines display multidrug resistant phenotype being, in addition to DOX, also resistant to other chemotherapeutic agents.

Cells were grown in monolayer in Falcon flasks (initial cell number $8 \times 10^{5}$ ) in RPMI-1640 (with glutamine), 10\% fetal bovine serum (FBS) (Hyclone, Europe Ltd., Cramlington, $\mathrm{UK})$, penicillin $(50 \mathrm{U} / \mathrm{ml})$, streptomycin $(50 \mu \mathrm{g} / \mathrm{ml})$ and nonessential amino acids in the same concentration as streptomycin, in a humidified atmosphere of $5 \% \mathrm{CO}_{2}$ in a waterjacketed incubator at $37^{\circ} \mathrm{C}$.

Treatments and clonogenic cytotoxicity assay. Cell viability assays were carried out using confluent cells. Cells were detached by addition of $10 \mathrm{mM}$ EDTA in phosphate-buffered saline (PBS), washed with PBS supplemented with $1 \%$ bovine serum albumin (BSA) and pelleted by centrifugation ( $2 \mathrm{~min}$, $1500 \mathrm{x} \mathrm{g})$. The cells were re-suspended in PBS/BSA. Aliquots of freshly harvested M14 cells $\left(10^{5} / \mathrm{ml}\right)$ were incubated at 37 or $42^{\circ} \mathrm{C}$ for different time intervals in the presence of the following reagents, used alone or in association: BSAO (17.20 $\mu \mathrm{g} / \mathrm{ml}$ corresponding to $1.01 \times 10^{-4} \mu$ moles $/ \mathrm{ml}$ or $\left.6.5 \times 10^{-3} \mathrm{IU} / \mathrm{ml}\right)$, spermine $(0-6 \mu \mathrm{M})$, exogenous acrolein $(12 \mu \mathrm{M})$ or hydrogen peroxide $(12 \mu \mathrm{M})$, catalase $(240 \mathrm{U} / \mathrm{ml})$ from bovine liver (Sigma), ALDH $(0.4 \mathrm{U} / \mathrm{ml})$ and $\mathrm{NAD}^{+}$ $(1.8 \mu \mathrm{g} / \mathrm{ml})$. The spermine solution was freshly prepared before each experiment and, if present, added last. Other cell survival experiments were performed using confluent cells that had been incubated during $24 \mathrm{~h}$ in RPMI-1640 medium containing MDL 72527 at 100 and $300 \mu \mathrm{M}$, in the presence of serum, at $37^{\circ} \mathrm{C}$. Incubations were carried out as above described, in the presence or absence of $\mathrm{BSAO} /$ spermine. After incubation the cells were centrifuged, washed twice in PBS/BSA, and re-suspended in $1 \mathrm{ml}$ PBS/BSA.

Cytotoxicity was evaluated by a plating efficiency assay, which determines the ability of the cells to form macroscopic colonies ( $>50$ cells). Aliquots of cell suspensions containing $10^{5}$ cells per $\mathrm{ml}$ were plated in tissue culture dishes $(50 \mathrm{~mm} \varnothing)$ containing $5 \mathrm{ml}$ complete culture medium, and were incubated 
at $37^{\circ} \mathrm{C}$. After 14 days, the colonies were fixed with $96 \%$ ethanol, stained with methylene blue and counted. Control plating efficiencies were higher than 85 and $80 \%$, for M14 WT and M14 ADR2 cells, corresponding to $9.1 \times 10^{4} \pm 1.0 \times 10^{4}$ and $8.5 \times 10^{4} \pm 1.0 \times 10^{4}$ number of cells, respectively. The percentage of colony forming cells was determined as the ratio between the mean number of colonies in treated and control samples.

Transmission electron microscopy (TEM). Transmission electron microscopy observations were performed using confluent cells that had been incubated during $24 \mathrm{~h}$ in RPMI-1640 medium containing MDL 72527 at $300 \mu \mathrm{M}$, in the presence of serum, at $37^{\circ} \mathrm{C}$. Then, cells were harvested as described above, washed with $\mathrm{PBS} / 1 \% \mathrm{BSA}$, centrifuged and re-suspended in $2 \mathrm{ml}$ of RPMI-1640 medium (without FBS). After incubation for $60 \mathrm{~min}$ at $37^{\circ} \mathrm{C}$ in the presence or absence of BSAO $\left(6.5 \times 10^{-3} \mathrm{IU} / \mathrm{ml}\right)$ and spermine $(6 \mu \mathrm{M})$, cells were washed with RPMI-1640 medium and then processed for TEM as described previously (33). Ultrathin sections were examined with a Philips EM 208S electron microscope (FEI Co., Eindhoven, The Netherlands).

Flow cytometry analyses. All flow cytometric analyses were carried out on cell suspensions $\left(\sim 10^{6}\right.$ cells $\left./ \mathrm{ml}\right)$ obtained by incubating monolayer cell cultures with EDTA. The fluorescent signals were analyzed by a FACScan LSRII flow cytometer (Becton-Dickinson, Mountain View, CA) equipped with an 15-mW, 488-nm, air-cooled argon ion laser and a Kimmon HeCd 325-nm laser. The fluorescence emissions were collected through a 530-nm band-pass filter for fluorescein isothiocyanate conjugated antibody (FITC, FL1), a 575-nm band-pass filter for propidium iodide (PI, FL2) and a 670-nm band-pass filter for acridine orange (FL3). At least 10,000 events/sample were acquired in linear (for cell cycle studies) or log mode (for P-gp expression, UIC2 shift, Annexin VFITC labeling and acridine orange staining). Percentages of cells in sub-G1, G1, S and G2/M phases of cell cycle and percentages of early and late apoptotic cells were calculated using the FACS Diva Software (Becton-Dickinson). For the quantitative evaluation of protein expression, UIC2 shift and acridine orange incorporation, FACS Diva Software was used to calculate mean fluorescence channel (MFC).

P-gp expression. For determination of cell surface P-glycoprotein (P-gp), cells were harvested with $10 \mathrm{mM}$ EDTA in PBS, washed by centrifugation ( $3 \mathrm{~min}, 1,500 \mathrm{~g})$ and resuspended in PBS-1\% BSA. Cell suspensions were then incubated for $20 \mathrm{~min}$ in PBS supplemented with $1 \%$ BSA, $10 \%$ FBS and $10 \%$ human serum $\mathrm{AB}$ in order to saturate aspecific sites. Cells were incubated with primary monoclonal antibody (MAb) MRK16 (Kamiya, Thousand Oaks, CA) for 30 min at $4^{\circ} \mathrm{C}$, washed with cold PBS and then incubated with goat anti-mouse IgG-fluorescein isothiocyanate conjugated (FITC) antibody (Sigma Chemical Co.) for $30 \mathrm{~min}$ at $4^{\circ} \mathrm{C}$. After washing with PBS, cells were immediately analyzed. For isotypic control, cells were labeled with $\operatorname{IgG2a}$, a mouse isotypic globulin (Sigma Chemical Co). Dead cells were excluded from the analysis by adding propidium iodide (PI, Sigma Chemical Co.) to the cell suspensions before the acquisition by flow cytometry.
UIC2 shift assay. M14 ADR2 cells $\left(\sim 10^{6}\right.$ cells/tube $)$ were harvested and resuspended in $1 \mathrm{ml}$ of PBS $+2 \% \mathrm{FBS}$ and allowed to equilibrate at $37^{\circ} \mathrm{C}$ in a water-bath for $10 \mathrm{~min}$. Different concentrations of MDL 72527 (25-300 $\mu \mathrm{M})$ or Cyclosporine A (CsA, Sigma Chemical Co.) $(5 \mu \mathrm{M})$ were added to samples, incubated at $37^{\circ} \mathrm{C}$ in a water bath for $10 \mathrm{~min}$ with periodic agitation, and incubated for an additional $15 \mathrm{~min}$ at $37^{\circ} \mathrm{C}$ with purified monoclonal antibody (MAb) UIC2 $(12.5 \mu \mathrm{g} / \mathrm{ml})$. UIC2 (Chemicon, Temecula, CA) is an IgG2a monoclonal immunoglobulin reacting with a conformational epitope of the 1st and 3rd loop of P-gp. Then, cells were washed twice in ice-cold PBS $+2 \%$ FBS, and stained on ice for 15 min with secondary FITC antibody; they were washed again twice with ice-cold PBS and analyzed by flow cytometry. Dead cells were excluded by using PI. For the quantitative evaluation of the increased fluorescence intensity, MFC was calculated by Diva software.

Determination of apoptotic cell death by Annexin V-FITC staining. To detect phosphatidylserine translocated from the inner face to the outer surface of plasma membrane in the initial step of apoptosis, an Annexin V-FITC kit (MBL, Medical \& Biological Laboratories Co., Ltd, Japan) was used (34). About 50 phosphatidylserine monomers are estimated to be bounded per each Annexin V molecule.

M14 WT and M14 ADR2 cells $\left(1 \times 10^{6} / \mathrm{ml}\right)$ were treated with $300 \mu \mathrm{M}$ MDL 72527 for $24 \mathrm{~h}$ or with BSAO $\left(6.5 \times 10^{-3} \mathrm{IU} /\right.$ $\mathrm{ml})$ and spermine $(6 \mu \mathrm{M})$ for $1 \mathrm{~h}$ at $37^{\circ} \mathrm{C}$ or with the combination MDL and BSAO/spermine. Cell suspensions were then plated in tissue culture-coated Petri dishes containing culture medium supplemented with FBS. After incubation at $37^{\circ} \mathrm{C}$ for $48 \mathrm{~h}$, cells were detached, centrifuged and resuspended in binding buffer (10 mM HEPES/NaOH, pH 7.5, $140 \mathrm{mM} \mathrm{NaCl}$, and $\left.2.5 \mathrm{mM} \mathrm{CaCl}_{2}\right)$. Cell suspension $\left(\sim 5 \times 10^{5}\right)$ was then incubated with $1 \mu \mathrm{g} / \mathrm{ml}$ of Annexin V-FITC and with $1 \mu \mathrm{g} / \mathrm{ml}$ of PI for $10 \mathrm{~min}$ at room temperature in the dark. The populations of Annexin V-FITC negative/PI negative cells (viable cells), Annexin V-FITC positive/PI negative cells (early apoptosis) and Annexin V-FITC positive/PI positive cells (late apoptosis) were evaluated by flow cytometry (34). The dot plots reported in Fig. 10 have been obtained from one out of three independent experiments which gave very comparable results.

Cell cycle analysis. Cell cycle distribution was analyzed by labelling cells with PI. Assays were carried out as described by Nicoletti et al (35). For cell sorting M14 WT and ADR2 cells $\left(1 \times 10^{6} / \mathrm{ml}\right)$, obtained from different treatments, as described in Annexin V-FITC labeling and acridine orange staining, were collected, washed twice with cold PBS and then centrifuged. The pellet was fixed in $70 \%$ ethanol in PBS at $4^{\circ} \mathrm{C}$ for $1 \mathrm{~h}$, washed twice and then re-suspended in PBS containing $100 \mu \mathrm{g} / \mathrm{ml}$ ribonuclease (RNAse). Cellular DNA was labelled with $40 \mu \mathrm{g} / \mathrm{ml} \mathrm{PI}$ in PBS and stored at $37^{\circ} \mathrm{C}$, at least $30 \mathrm{~min}$ (Sigma-Aldrich, St. Quentin Fallavier, France). After incubation cells were analyzed by flow cytometry.

Confocal microscopy observations and quantification of acidic vacuoles. To analyze by laser scanning confocal microscopy (LSCM) the formation of acidic vacuoles in 
melanoma cells, induced by treatment with MDL 72527, the vital staining with acridine orange solution was performed. Cells were grown on the coverslips until confluent state and then treated with the lysosomotropic compound for $24 \mathrm{~h}$. They were incubated with acridine orange solution $(2.5 \mu \mathrm{g} / \mathrm{ml})$ for $15 \mathrm{~min}$ at $37^{\circ} \mathrm{C}$; after $20 \mathrm{~min}$ in drug-free medium at $37^{\circ} \mathrm{C}$, they were washed with PBS and immediately observed. The observations of acidic vacuoles were carried out using a Leica TCS SP2 spectral confocal microscope (Leica Microsystems, Wetzlar, Germany) equipped with Argon-Helium-Neon lasers. In these organelles, the stacked form of acridine orange generates a bright red fluorescence (FL3); on the contrary in the nucleus and cytoplasm, unstacked acridine orange displays variable green fluorescence (FL1). Quantification of lysosomotropic effect induced by MDL 72527 compound on M14WT and ADR2 cells was performed by flow cytometry, after staining with acridine orange solution.

Statistical analysis. Values reported in the figures and the tables are means \pm standard deviation (SD) from 3-6 independent experiments. Statistical analyses were performed using Student's t-test, with $\mathrm{p}<0.05$ considered significant.

\section{Results}

P-gp expression in M14 melanoma cells. The pleiotropic MDR melanoma cell line, M14 ADR, and its drug-sensitive parental line, M14 WT, were characterized in a previous study for their sensitivity to anti-tumoral drug DOX and for the expression of the transporter molecule P-gp (32). In order to better highlight the cytotoxic effect of the spermine metabolites on MDR cells and the possible sensitizing action exerted by the lysosomotropic compound, as MDL 72527, M14 ADR cells were further cultivated in medium in presence of $10 \mu \mathrm{M}$ DOX. The treatment was performed for several passages, except for the final passage before experiments, for enhancing the resistance index of M14 ADR cells, thus generating the new melanoma cell line M14 ADR2. Then, the wild-type and the two resistant lines were analyzed by flow cytometry for the surface expression of P-gp after labelling with the anti-P-gp MAb MRK16. As shown in Fig. 1, the intensities of the fluorescent signals of M14 ADR and M14 ADR2 cell lines were much higher than that of M14 WT cells. In control cells labelled with an irrelevant antibody the fluorescence profile was coincident with that of M14 WT cells. In particular, the fluorescence intensity ratio between M14 ADR and M14 WT cells was about 25, while between M14 ADR2 and M14 WT cells was more than 300 indicating that the expression of the drug transporter P-gp in the new resistant cell line, M14 ADR2, was about 12-fold higher than in M14 ADR line.

Loss of viability of M14 WT and M14 ADR2 cells due to exposure to BSAO and spermine: effect of catalase and $A L D H$ on the cytotoxicity of spermine metabolites. The contribution of the enzymatically formed cytotoxic products of spermine was compared with that of exogenous hydrogen peroxide and aldehyde to cytotoxicity. Since acrolein is considered as the potential cytotoxic product of spermine (36), and since it is not known which of the aldehydes is formed preferentially

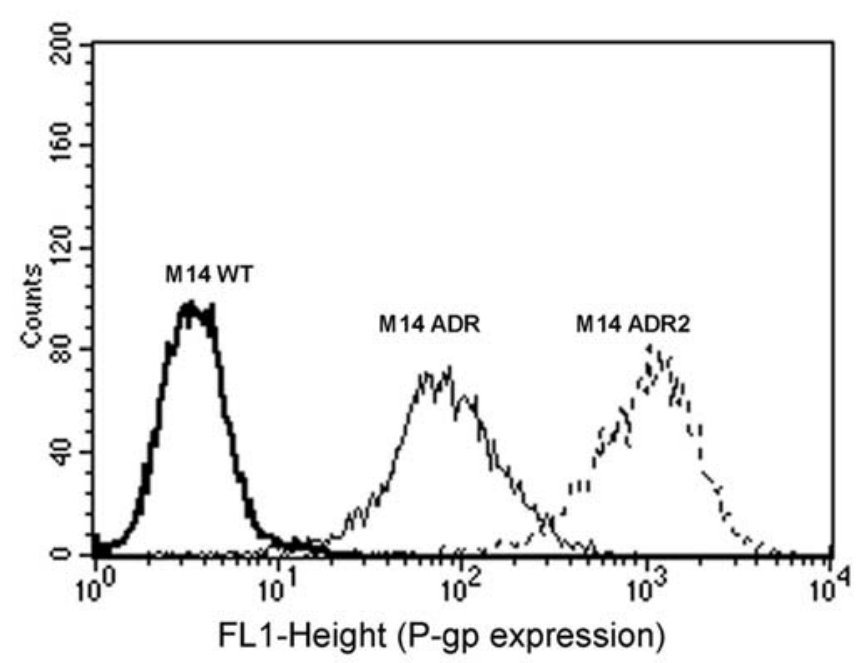

Figure 1. Characterization of melanoma cell lines. Flow cytometric analysis of surface P-gp expression on M14 WT and MDR cells after labelling with MAb MRK16. M14 WT, parental sensitive cells; M14 ADR, resistant variants with lower resistance index; M14 ADR2, resistant variants with higher resistance index, derived from M14 ADR cultured in presence of $10 \mu \mathrm{M}$ DOX

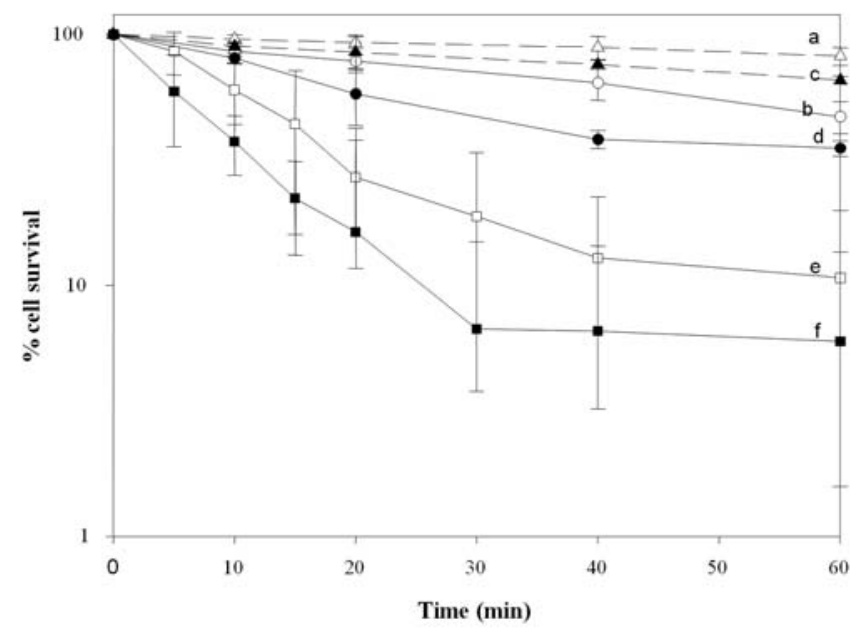

Figure 2. Effect of exogenous hydrogen peroxide and acrolein on M14 cell viability in comparison with the effect of BSAO and spermine. M14 WT (open symbols) and M14 ADR2 cells (black symbols) were incubated with $6 \mu \mathrm{M}$ acrolein (dashed lines, $\Delta ; \mathbf{\Delta}$ ), or $6 \mu \mathrm{M}$ hydrogen peroxide (solid lines, $\circ ; \bullet$ ), or $6.5 \times 10^{-3} \mathrm{IU} / \mathrm{ml} \mathrm{BSAO}$ and $6 \mu \mathrm{M}$ spermine (solid lines, $\square$; $\boldsymbol{\square}$ ) up to $60 \mathrm{~min}$ at $37^{\circ} \mathrm{C}$. Subsequently plating efficiency was determined. Means \pm SD are shown for three to six estimations for four to six experiments. Where not shown, SDs lie within the symbols. See the text for details of curves a-f.

from spermine under the experimental conditions $(10,11)$, acrolein was used as a model compound. The effect of 60-min incubations with $6 \mu \mathrm{M}$ hydrogen peroxide and $6 \mu \mathrm{M}$ acrolein is shown in Fig. 2. After 60 min of incubation of M14 WT cells, hydrogen peroxide reduced cell viability $\sim 50 \%$ (curve b) and acrolein $\sim 20 \%$ (curve a). The corresponding values for M14 ADR2 cells are 65 and 35\% (curves d and c, respectively). If cells were exposed to both compounds at the same time, viability decreased by $65 \%$ in M14 WT and $80 \%$ in M14 ADR2 cells (not shown). BSAO $\left(6.5 \times 10^{-3} \mathrm{IU} / \mathrm{ml}\right)$ and 


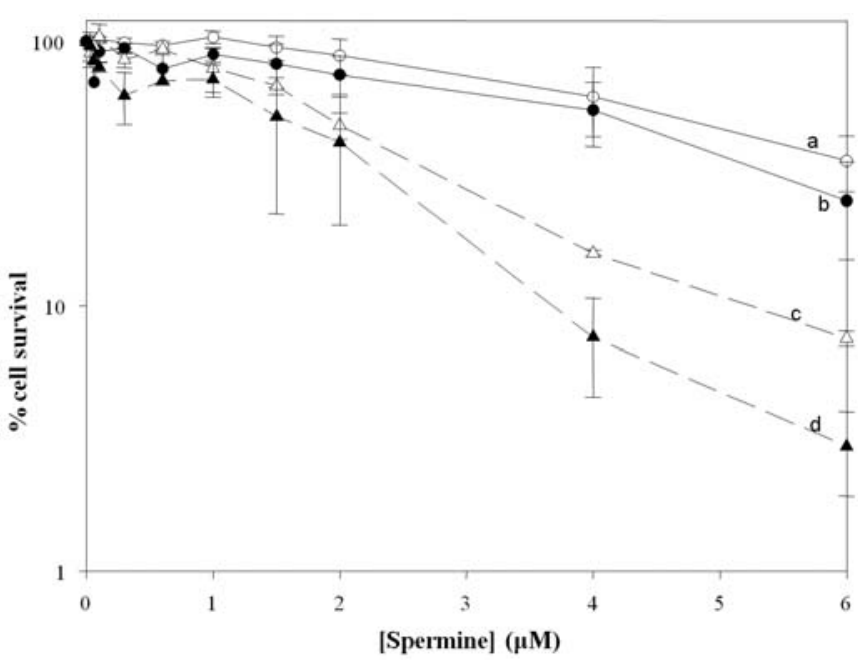

Figure 3. Effect of BSAO and spermine on the survival of M14 melanoma cells as a function of spermine concentration. M14 WT (open symbols) and M14 ADR2 cells (black symbols) were incubated in the presence of $6.5 \times 10^{-3} \mathrm{IU} / \mathrm{ml} \mathrm{BSAO}$ and spermine at concentrations ranging between 0 and $6 \mu \mathrm{M}$ for $60 \mathrm{~min}$ at $37^{\circ} \mathrm{C}$ (solid lines, $\left.\circ ; \bullet\right)$ or $42^{\circ} \mathrm{C}$ (dashed lines, $\Delta ; \Delta$ ), followed by the determination of the percentage of surviving cells by a plating assay. Means \pm SD are shown for three to six estimations for four to six experiments. Where not shown, SDs lie within the symbols. See the text for details of curves a-d.

$6 \mu \mathrm{M}$ spermine were considerably more potent than exogenous acrolein or hydrogen peroxide. After BSAO/spermine treatment for $60 \mathrm{~min}$, cell viability decreased $\sim 90 \%$ in M14 WT, and 96\% in M14 ADR2 cell lines (curves e and f, respectively). However, more importantly, not only the maximum toxicity was higher in the case of treatment with BSAO and spermine, but also the initial rate of decrease in cell viability was significantly higher than with the presumed cytotoxic products of spermine, as is evident from Fig. 2 .

The sensitivity of numerous cancer cell lines to an increase of the temperature above $37^{\circ} \mathrm{C}$ is the basis of clinical hyperthermia. In the presence of $\mathrm{BSAO}$ and low concentration $(<1.5 \mu \mathrm{M})$ of spermine no cytotoxic effect was observed at $37^{\circ} \mathrm{C}$. However, an increase of the incubation temperature to $42^{\circ} \mathrm{C}$ resulted in a significant increase in cytotoxicity after 60 min of incubation at a concentration $>2 \mu \mathrm{M}$ spermine, as shown in Fig. 3.

The initial decrease of cell viability is mostly due to hydrogen peroxide. This was shown by addition of catalase to the incubation mixture. As shown in Fig. 4, the cytotoxicity of the BSAO-catalyzed products was reduced in the presence of $240 \mathrm{U} / \mathrm{ml}$ catalase within $15 \mathrm{~min} \sim 91$ and $67 \%$ for wild-type and MDR cells, respectively (curves a and b). Conversion of acrolein to acrylic acid by addition of ALDH $(0.4 \mathrm{U} / \mathrm{ml})$ and $\mathrm{NAD}^{+}(1.8 \mu \mathrm{g} / \mathrm{ml})$ reduced cell viability at the same time only $\sim 30 \%$ for wild-type and $\sim 10 \%$ for M14 ADR2 cells (curves c and d). Sixty $\mu \mathrm{M}$ acrolein are required, to decrease cell viability by $90 \%$, whereas $18 \mu \mathrm{M}$ hydrogen peroxide killed M14 cells completely within $60 \mathrm{~min}$ at $37^{\circ} \mathrm{C}$ (not shown), indicating that under the present experimental conditions the cytotoxicity attributed to hydrogen peroxide is considerable more important than that of acrolein or of other aldehydes deriving from spermine.

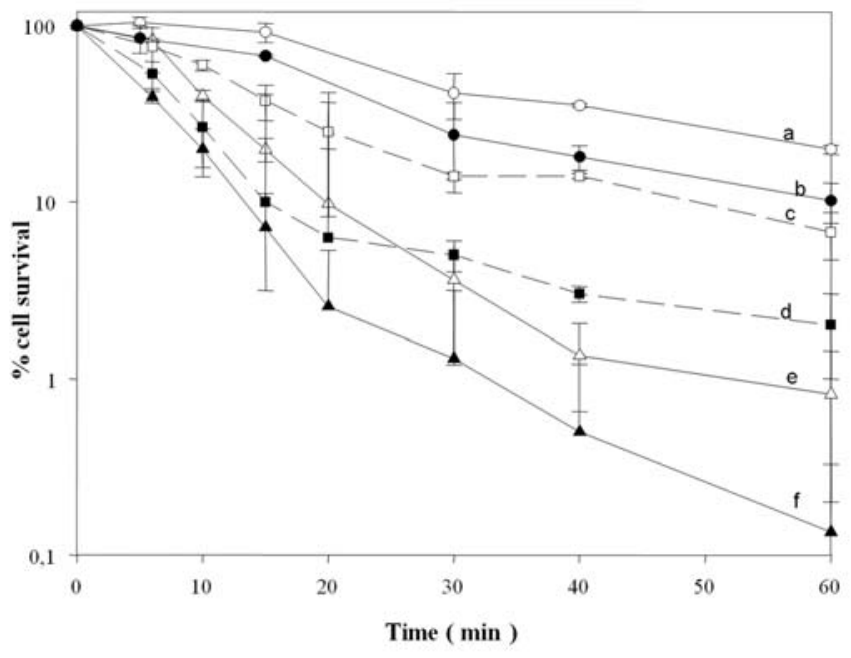

Figure 4. Effect of BSAO and spermine on the survival of M14 melanoma cells in the presence or absence of catalase and ALDH. M14 WT (open symbols) and M14 ADR2 cells (black symbols) were incubated in the presence of $6.5 \times 10^{-3} \mathrm{IU} / \mathrm{ml} \mathrm{BSAO}$ and $6 \mu \mathrm{M}$ spermine up to $60 \mathrm{~min}$ at $42^{\circ} \mathrm{C}$, in the absence (solid lines, $\triangle ; \Delta$ ) or presence of $240 \mathrm{U}$ catalase (solid lines, $\bullet ; \bullet$ ) or $0.4 \mathrm{U} \mathrm{ALDH}$ and $\mathrm{NAD}^{+}(1.8 \mathrm{mg} / \mathrm{ml})$ (dashed lines, $\square$; $\left.\boldsymbol{\square}\right)$, followed by the determination of the percentage of surviving cells by a plating assay. Means \pm SD are shown for three to six estimations for four to six experiments. Where not shown, SDs lie within the symbols. See the text for details of curves a-f.

Cell viability decreases as a function of the incubation time. The MDR cells were considerably more sensitive to the treatment with BSAO and spermine, than the corresponding WT cells, as is evident comparing curves f and e of Fig. 4.

Sensitization of M14 cells to BSAO/spermine-induced toxicity by MDL 72527. MDL 72527 is known as an inactivator of polyamine oxidase, but also as a cytotoxic agent with lysosomotropic properties $(28,37)$. In our experimental conditions both sensitive and multidrug-resistant M14 cells were quite insensitive to MDL 72527 when added alone: incubation with $300 \mu \mathrm{M}$ of this drug for $24 \mathrm{~h}$ at $37^{\circ} \mathrm{C}$ had no significant effect on cell survival (Fig. 5 curves a and b). When preincubation with $300 \mu \mathrm{M}$ MDL 72527 for $6 \mathrm{~h}$ was followed by exposure to $\mathrm{BSAO}$ and $6 \mu \mathrm{M}$ spermine, the survival of both cell lines, M14 WT and M14 ADR2, decreased (curves e and $\mathrm{f}$, respectively) respect to the treatment with $\mathrm{BSAO} /$ spermine alone (curves $\mathrm{c}$ and d). Again, M14 ADR2 cells (curve f) responded more sensitively to the treatments than M14 WT cells (curve e). A similar effect was observed after pre-incubation with $100 \mu \mathrm{M}$ MDL 72527 for a longer time $(24 \mathrm{~h})$, followed by treatment with BSAO and $6 \mu \mathrm{M}$ spermine (curves $\mathrm{h}$ and $\mathrm{g}$ ).

Effect of MDL 72527 on P-gp conformation detected by MAb UIC2 shift assay. As reported above, the resistant phenotype is mainly due to overexpression of $\mathrm{P}$-gp in the plasma membrane of tumor cells. P-gp undergoes conformational changes when carrying out its transport activity. In order to verify if MDL 72527 was a substrate of P-gp, the effect of this compound on the reactivity of the monoclonal antibody MAb UIC2 was investigated on M14 ADR2 cells. The MAb UIC2 specifically recognizes a conformational epitope of the 


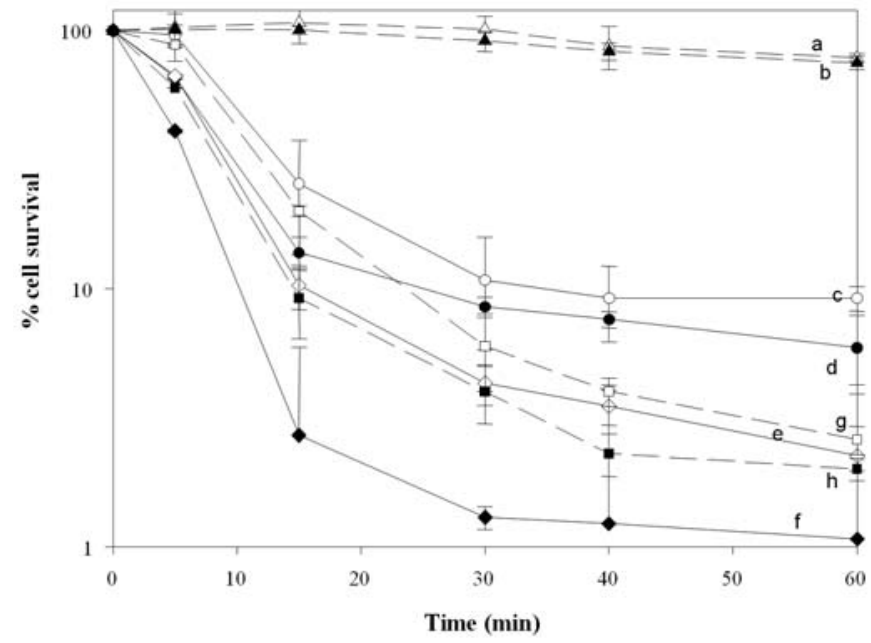

Figure 5. Effect of pre-incubation with 100 and $300 \mu \mathrm{M}$ MDL 72527 on the sensitivity of M14 melanoma cells to cytotoxic polyamine metabolites. M14 WT (open symbols) and M14 ADR2 cells (black symbols) were incubated with $300 \mu \mathrm{M}$ MDL 72527 alone for $24 \mathrm{~h}$ (dashed lines, $\triangle$; $\Delta$ ), or: i) preincubated with $100 \mu \mathrm{M}$ MDL 72527 for $24 \mathrm{~h}$ (dashed lines, $\square$; $\mathbf{a})$; or ii) with $300 \mu \mathrm{M}$ MDL 72527 for $6 \mathrm{~h}$ (solid lines, $\diamond$; $)$. After pre-incubation, (i) and (ii) cells were washed and then exposed up to $60 \mathrm{~min}$ to BSAO $\left(6.5 \times 10^{-3} \mathrm{IU} / \mathrm{ml}\right)$ and spermine $(6 \mu \mathrm{M})$ at $37^{\circ} \mathrm{C}$, followed by the clonogenic assay. Control cells were only incubated with BSAO $\left(6.5 \times 10^{-3} \mathrm{IU} / \mathrm{ml}\right)$ and spermine $(6 \mu \mathrm{M})$ (solid lines, $\diamond ; \bullet)$. Means \pm SD are shown for three to six estimations for four to six experiments. Where not shown, SDs lie within the symbols. See the text for details of curves a-h.

drug transporter and its reactivity is closely related to the functional state of P-gp in extruding their substrates. In particular, the effect of MDL 72527 treatment, in the concentration range of $0-300 \mu \mathrm{M}$, on the reactivity of the $\mathrm{MAb}$ UIC2, was analyzed by flow cytometry and compared with those induced by CsA, a widely accepted MDR revertant.

Cytofluorimetric profiles (Fig. 6) showed a clear modulating effect exerted by MDL 72527 on the reactivity of MAb UIC2. After treatment with either 25 or $300 \mu \mathrm{M}$ MDL 72527 , the expression of the UIC2 epitope in M14 ADR2 cells was about doubled when compared to untreated cells. As expected, in the same experiment CsA, used as positive control, induced a similar UIC2 shift.

These results suggested that MDL 72527 is a substrate of $\mathrm{P}$-gp; therefore, in the present investigation, the non-cytotoxic $300 \mu \mathrm{M}$ concentration of MDL 72527 was chosen in order to sensitize melanoma cells to spermine metabolites.

Ultrastructural alterations. With the aim to investigate on subcellular targets of the cytotoxic polyamine metabolites (hydrogen peroxide and aldehydes), TEM was used. Control M14 WT and M14 ADR2 cells grown at $37^{\circ} \mathrm{C}$ showed a well-preserved ultrastructure of cytoplasmic organelles and mitochondria (arrows) (Fig. 7a and b, respectively). The treatment with $300 \mu \mathrm{M}$ of MDL 72527 for $24 \mathrm{~h}$ produced in M14 WT cells (Fig. 7c) the appearance of a large number of lysosomes (arrows) and cytoplasmic vacuoles (arrow heads). Lysosomes showed either osmiophilic content or incompletely hydrolysed material; the other cytoplasmic organelles (i.e., mitochondria) appeared well preserved. The cytoplasm of M14 ADR2 cells treated with MDL 72527 was

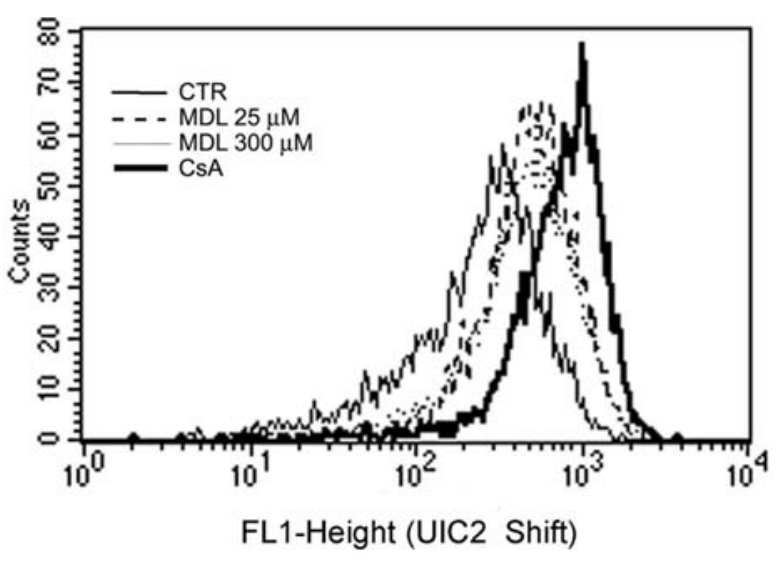

Figure 6. Effect of MDL 72527 on P-gp conformation detected by UIC2 shift assay. Cytofluorimetric profiles showing the reactivity modulation of Anti-P-gp MAb UIC2 induced by MDL $72527(25$ and $300 \mu \mathrm{M})$ and CsA $(5 \mu \mathrm{M})$ on M14 ADR2 cells.

characterized by a lower number of lysosomes, different in shape and size (arrows), than WT cells, and small cytoplasmic vacuoles (arrow heads) (Fig. 7d). After exposure to BSAO and $6 \mu \mathrm{M}$ spermine at $37^{\circ} \mathrm{C}$ for $60 \mathrm{~min}, \mathrm{M} 14 \mathrm{WT}$ cells did not show significant ultrastructural modifications (Fig. 7e). On the contrary, the mitochondria of MDR cells showed shrunken matrix and swollen cristae (Fig. 7f). In M14 WT cells pre-treated for $24 \mathrm{~h}$ with MDL 72527 and then treated with BSAO and spermine (Fig. 7g), several cytoplasmic vacuoles were observed. Mitochondria appeared highly damaged, with swollen matrices and fragmented cristae (arrows). Numerous lysosomes containing fragmented cell debris (arrow head) were also visible. After the same treatment, resistant M14 ADR2 cells showed characteristic ultrastructural alterations (Fig. 7h). Particularly evident was the formation of peculiar cytoplasmic organelles (arrows) suggestive of dramatic reorganization of mitochondrial architecture, followed by fragmentation. This seems to be demonstrated by the presence in the cytoplasm of numerous 'nano-mitochondria' with similar structure.

Lysosomal membrane permeabilization evaluated by confocal microscopy and flow cytometry. The impairment of lysosomal membrane integrity of M14 WT and M14 ADR2 cells by MDL 72527 was investigated under identical conditions as those used for the analysis of ultrastructural changes. To gain insight into the mechanism, the vital staining with acridine orange was performed. Laser scanning confocal microscopy observations showed that the treatment of both cell lines with $300 \mu \mathrm{M}$ of MDL 72527 for $24 \mathrm{~h}$ (Fig. 8c and d) increased the number of lysosomal structures when compared to the respective controls (Fig. 8a and b). Such as effect resulted more marked in M14 WT than M14 ADR2 cells. Moreover, while in control cells red fluorescence was concentrated in a perinuclear area of the cytoplasm, it appeared dispersed over the entire cell after treatment. This observation is compatible with the release of acridine orange from the lysosomes into the cytoplasm due to the permeabilization of the lysosomal membrane. It is also supported by the ultrastructural changes (TEM), as described above (Fig. 7c and d)

To quantify the amount of acidic compartments, flow cytometric analysis of acridine orange stained cells, using 

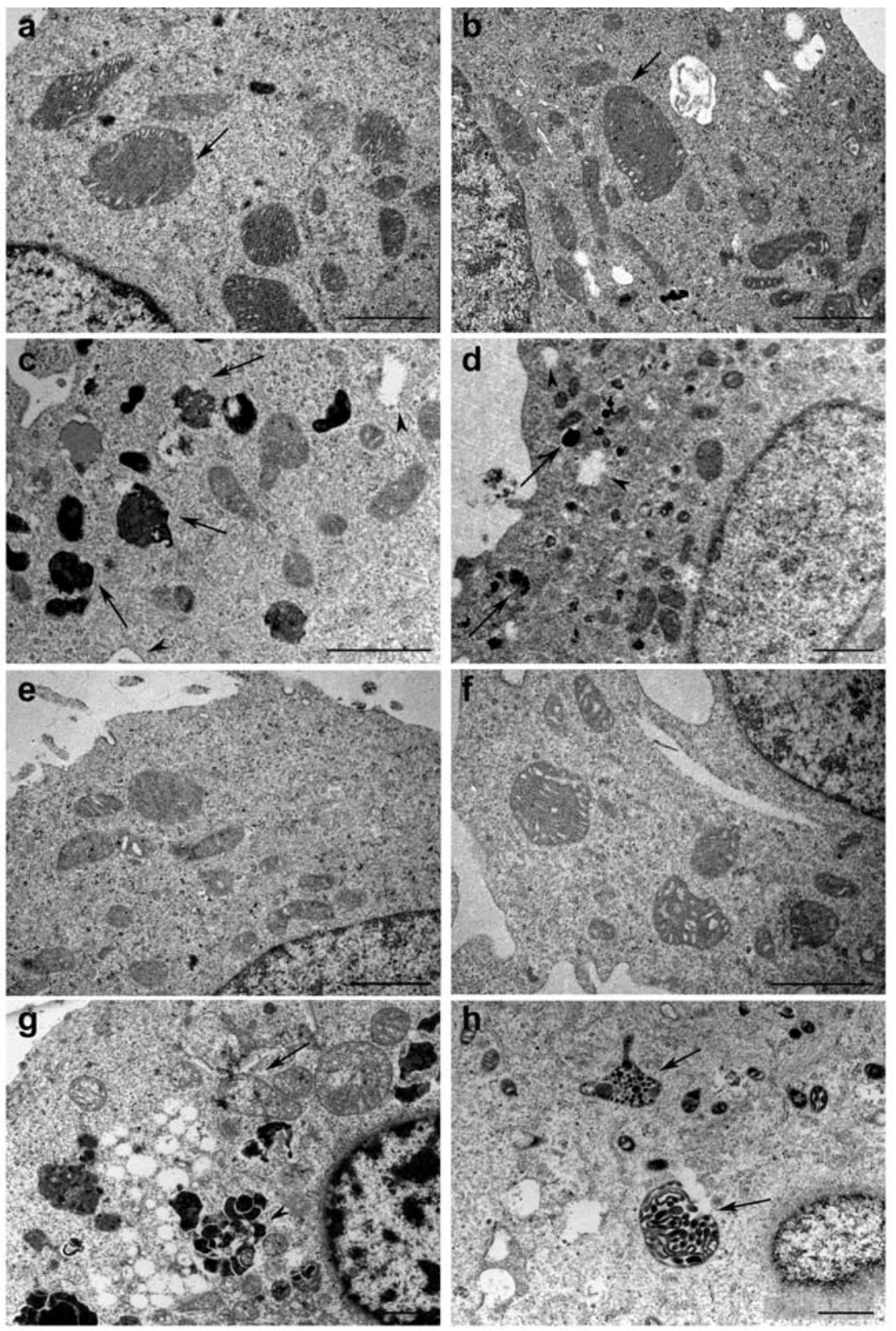

Figure 7. Ultrastructural analysis of M14 WT (left panels) and M14 ADR2 (right panels) cells performed by transmission electron microscopy. (a and b) Untreated melanoma cells; (c and d) Cells exposed to $300 \mu \mathrm{M}$ MDL 72527 for $24 \mathrm{~h}$, at $37^{\circ} \mathrm{C}$; (e and f) Cells treated for $60 \mathrm{~min}$ with $6.5 \times 10^{-3} \mathrm{IU} / \mathrm{ml} \mathrm{BSAO}$ and $6 \mu \mathrm{M}$ spermine at $37^{\circ} \mathrm{C}$; (g and h) Cells were first exposed for $24 \mathrm{~h}$ to $300 \mu \mathrm{M}$ MDL 72527 , and then treated for $60 \mathrm{~min}$ with $6.5 \times 10^{-3} \mathrm{IU} / \mathrm{ml} \mathrm{BSAO}$ and $6 \mu \mathrm{M}$ spermine at $37^{\circ} \mathrm{C}$. Bars, $2 \mu \mathrm{m}$.

FL3 mode (>650 nm), was performed. As shown in Fig. 9, MDL 72527 treatment increased the intensity of the red fluorescence signal in comparison with the control cells. The enhancement was more evident in M14 WT cells (Fig. 9a) than M14 ADR2 counterparts (Fig. 9b). The difference between control and treated cells was statistically significant in the sensitive line $(\mathrm{p}=0.05)$ whereas in resistant line, even if observed in all the determinations, was scarcely significant $(\mathrm{p}=0.13)$, accounting for the finding that demonstrated MDL 72527 as a substrate of P-gp, overexpressed by MDR cells, as above described. These observations further suggest the lysosomotropic activity exerted by MDL 72527.

Analysis of apoptosis induction by flow cytometry. Annexin V, a $\mathrm{Ca}^{2+}$-dependent phospholipid-binding protein with a high affinity for phosphatidylserine (38), was used to detect the early stage of apoptosis in melanoma cells treated with MDL 72527 alone, or with BSAO/spermine enzymatic system and in cells pre-treated with MDL 72527 and then treated with $\mathrm{BSAO} /$ spermine.

The results of the flow cytometric analysis are shown in Fig. 10. After treatment of melanoma cells, WT and ADR2, with BSAO and spermine $6 \mu \mathrm{M}$ for $60 \mathrm{~min}$ at $37^{\circ} \mathrm{C}$ (Fig. 10e and $\mathrm{f}$ ), the fraction of Annexin $\mathrm{V}$ positive/PI negative cells in early apoptosis, 22.8 and $17.6 \%$, respectively, was higher than the fraction Annexin V positive/PI positive cells, 12.1 and $6.0 \%$, respectively. In both cell lines the treatment with $300 \mu \mathrm{M}$ of MDL 72527 did not significantly modify the two apoptotic fractions (Fig. 10c and d), that were similar to untreated control cells (Fig. 10a and b). Instead, if the pre- 

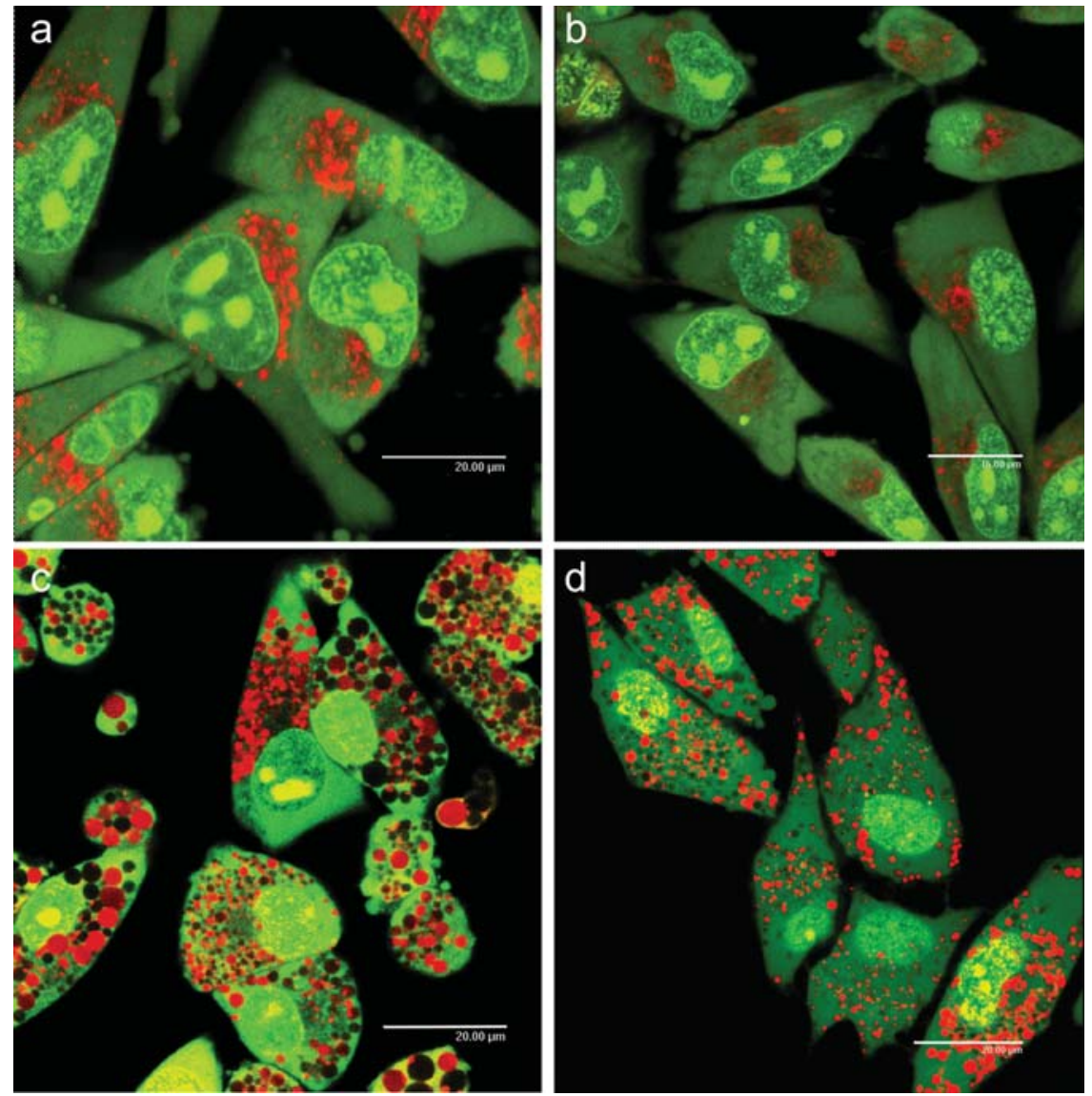

Figure 8. Effect of MDL 72527 treatment on the intracellular distribution of acridine orange-positive structure in M14 cells observed by confocal microscopy. Acridine orange-stained M14 WT (a) and M14 ADR2 (b) control cells; M14 WT (c) and M14 ADR2 (d) cells exposed to $300 \mu$ M MDL 72527 for 24 h, at $37^{\circ} \mathrm{C}$.

a

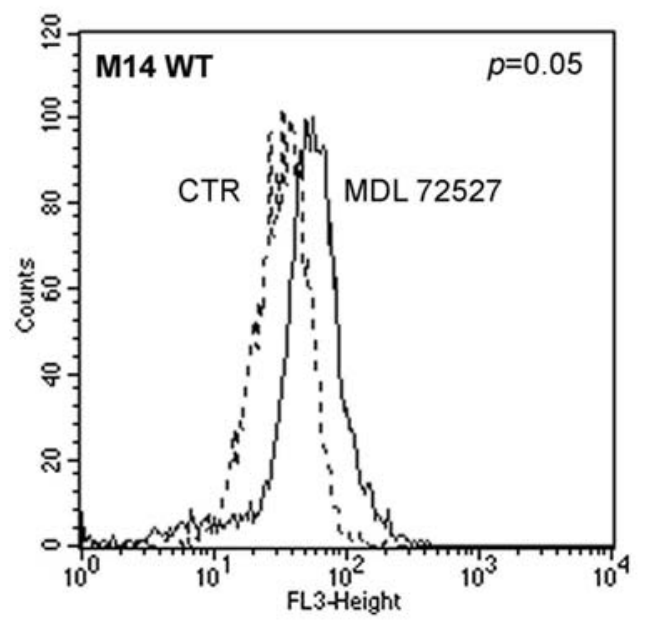

b

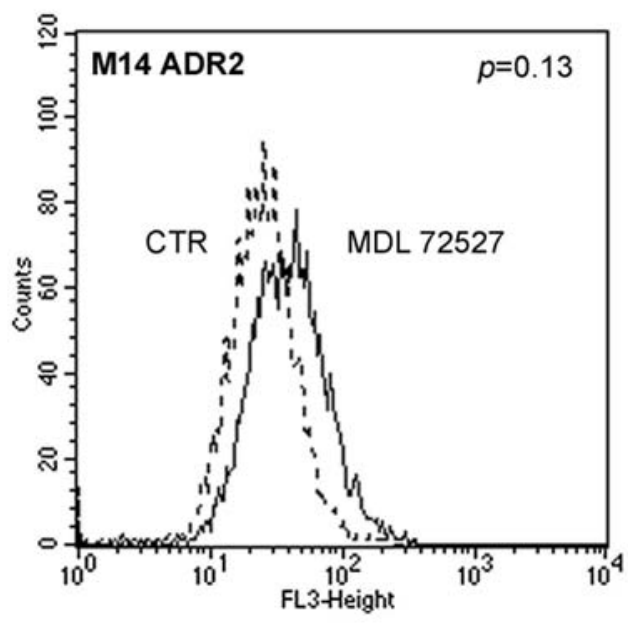

Figure 9. Lysosomotropic effect of MDL 72527 evaluated by flow cytometry analysis. Quantification of lysosomotropic effect induced by $300 \mu$ M MDL 72527 in acridine orange-stained M14 WT (a) and M14 ADR2 (b) cells.

treatment with MDL 72527 was followed by exposure to BSAO and spermine, it slightly modified the two fractions of apoptotic process in M14 WT cells, $37.7 \%$ respect to $34.9 \%$ (Fig. $10 \mathrm{~g}$ and e), whereas a noticeable increase of early and late apoptotic cells was revealed on M14 ADR2 cells, $42.8 \%$ respect to $23.6 \%$ ) (Fig. 10h and f). These findings are in agreement with the enhancement of the cytotoxic effect of the oxidation products of spermine, sensitized by MDL 72527, particularly on melanoma cells exhibiting MDR phenotype. 

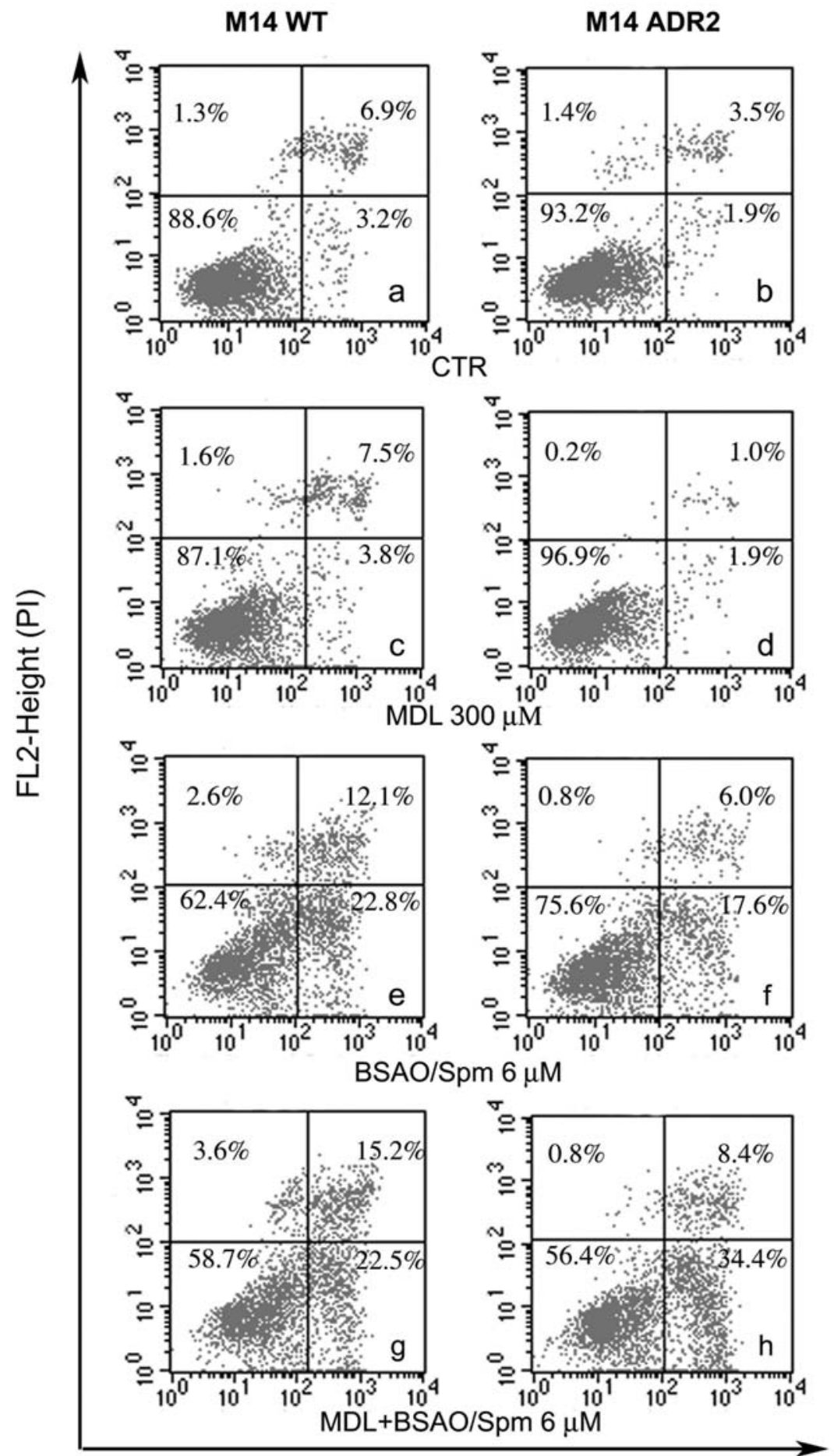

FL1-Height (Annexin V-FITC)

Figure 10. Flow cytometric analysis of apoptosis performed on M14 WT (left panels) and M14 ADR2 (right panels) cells after double labelling with Annexin V-FITC and PI. (a and b) Untreated melanoma cells; (c and d) Cells exposed to $300 \mu \mathrm{M}$ MDL 72527 for $24 \mathrm{~h}$, at $37^{\circ} \mathrm{C}$; (e and f) Cells treated for 60 min with $6.5 \times 10^{-3} \mathrm{IU} / \mathrm{ml} \mathrm{BSAO}$ and $6 \mu \mathrm{M}$ spermine at $37^{\circ} \mathrm{C}$; ( $\mathrm{g}$ and h) Cells first exposed for $24 \mathrm{~h}$ to $300 \mu \mathrm{M}$ MDL 72527 , and then treated for $60 \mathrm{~min}$ with $6.5 \mathrm{x} .10^{-3} \mathrm{IU} / \mathrm{ml}$ $\mathrm{BSAO}$ and $6 \mu \mathrm{M}$ spermine at $37^{\circ} \mathrm{C}$. Dot plots have been obtained from one out of three experiments, performed in the same experimental conditions, which gave very similar results.

To confirm the involvement of apoptotic cell death, we investigated the presence of sub-G1 peak analyzing cell cycle by flow cytometry (Fig. 11). Treatment with $300 \mu \mathrm{M}$ of MDL 72527 alone, as expected, did not modify cytometric profile of either cell line (Fig. 11c and d), being very similar to respective control cells (Fig. 11a and b). Incubation with
BSAO and spermine $6 \mu \mathrm{M}$ induced a remarkable appearance of subG1 peak (15.7\%) on M14 WT cells (Fig. 11e), that was slightly increased $(17.7 \%)$ when cells were pre-treated with MDL 72527 and then treated with BSAO/spermine (Fig. 11g). Instead, analysis of cytometric profile of M14 ADR2 cells treated with BSAO/spermine enzymatic system (Fig. 11f) 
M14 WT

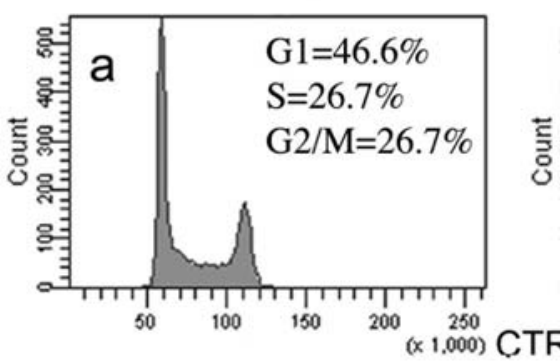

M14 ADR2

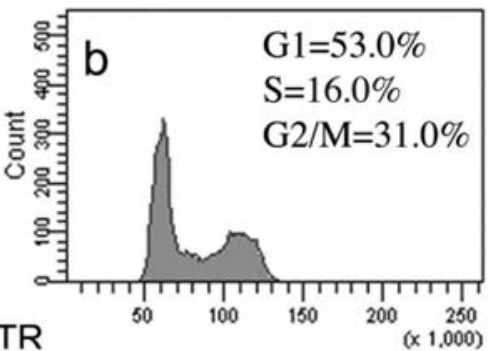

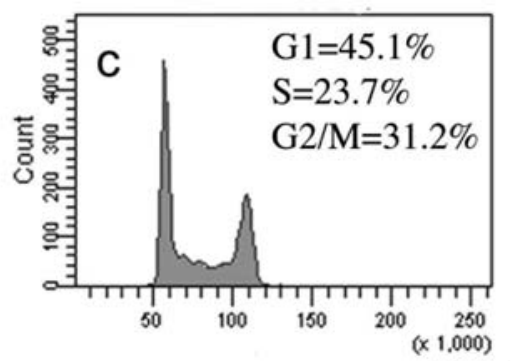

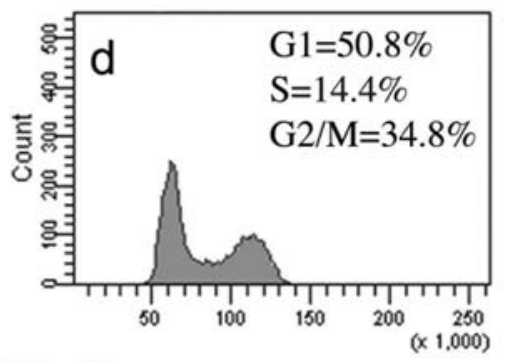

MDL $300 \mu \mathrm{M}$
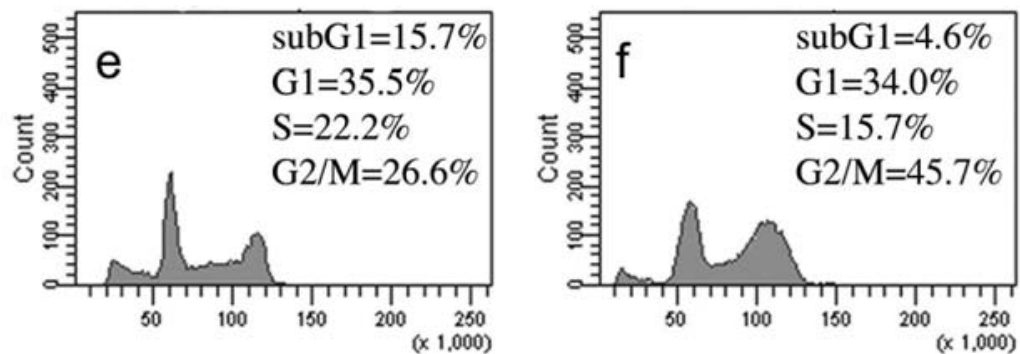

$\mathrm{BSAO} / \mathrm{Spm} 6 \mu \mathrm{M}$

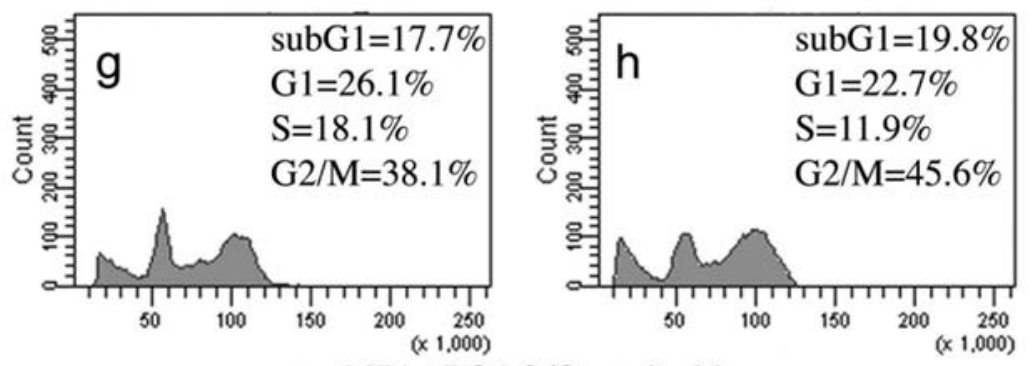

$\mathrm{MDL}+\mathrm{BSAO} / \mathrm{Spm} 6 \mu \mathrm{M}$

\section{FL2-Area (DNA Content)}

Figure 11. Cell cycle analysis of M14 WT (left panels) and M14 ADR2 (right panels) cells by flow cytometry. (a and b) Untreated melanoma cells; (c and d) Cells exposed to $300 \mu \mathrm{M}$ MDL 72527 for $24 \mathrm{~h}$, at $37^{\circ} \mathrm{C}$; (e and f) Cells treated for $60 \mathrm{~min}$ with $6.5 \times 10^{-3} \mathrm{IU} / \mathrm{ml} \mathrm{BSAO}$ and $6 \mu \mathrm{M}$ spermine at $37^{\circ} \mathrm{C}$; (g and h) Cells first exposed for $24 \mathrm{~h}$ to $300 \mu \mathrm{M}$ MDL 72527 , and then treated for 60 min with $6.5 \times 10^{-3} \mathrm{IU} / \mathrm{ml}$ BSAO and $6 \mu \mathrm{M}$ spermine at $37^{\circ} \mathrm{C}$. The results are representative of one out of three experiments carried out in the same experimental conditions, which gave very similar results.

showed a slightly increase of hypodiploid fraction $(4.6 \%)$ and a noticeable increase of percentage of cells in $\mathrm{G} 2 / \mathrm{M}$ phase $(45.7 \%)$ in comparison with untreated cells. The hypodiploid fraction of M14 ADR2 cells increased to $19.8 \%$ after combined treatment (Fig. 11h), confirming the potentation of spermine enzymatic oxidation product cytotoxicity by MDL 72527 and suggesting the involvement of the apoptotic mechanisms.

\section{Discussion}

Although still at a beginning, enzymatically formed ROS have certain potential in cancer therapy $(14,28,39)$. In previous reports we discussed the effect of cytotoxic metabolites of spermine, hydrogen peroxide and aldehydes, on several cell lines $(10,40)$, including human melanoma (M14) (11) and mouse melanoma tumor cells (B16-F0) (24). The growth 
of a mouse melanoma was inhibited by exposure to BSAO and spermine (24) and for the slow release of toxic enzymatic oxidation products of spermine into the tumor, the use of BSAO conjugated to biocompatible polymers was considered $(24,41)$. However, in the case of BSAO, the administration of the substrate spermine, might be unnecessary in a new therapeutic approach, since tumor cells have high polyamine concentrations $(21,39,42)$, and the polyamines are released into the cellular environment, if cells are damaged (14). Therefore, the present work has the aim to further improve our knowledge of polyamine-derived cytotoxic products in causing cell death.

The prevention of cytotoxicity of spermine metabolites by catalase and ALDH confirmed previous results obtained among others, with human LoVo cells (15) or B16-F0 tumor cells (25), and showed that in the initial phase of spermine oxidation mainly hydrogen peroxide is effective as cytocidal agent, whereas the aldehydes formed from spermine are active only after their accumulation at a later stage of enzymatic reaction (incubation time $>30 \mathrm{~min}$ ). These effects were observed at both 37 and $42^{\circ} \mathrm{C}$, although cytotoxicity is higher at the elevated incubation temperature $(15,43)$. In view of the sensitivity of human cancer cell lines to hydrogen peroxide, and in order to allow observing intermediary stages of cell damage, an experimental protocol was chosen that produces a slow release of metabolites over a limited period of time.

Comparing the cytotoxic effect of $6 \mu \mathrm{M}$ spermine in the presence of BSAO, with that of the same concentrations of exogenous hydrogen peroxide and acrolein, the enzymatically formed spermine metabolites were considerably more toxic than the individual agents or the combination of hydrogen peroxide and acrolein, in spite of the gradual release of the spermine metabolites, and their low concentration during the initial incubation period. This apparently paradoxical result may be explained by the binding BSAO to the cell membrane, and its internalization, and the release of the toxic metabolites of spermine into the cells, or the close vicinity of the cell surface, where they would be present at high concentration. It has been demonstrated that hepatocytes express binding sites for BSAO (44). It is likely that M14 melanoma cells express similar binding sites of BSAO. Fluorimetric determinations showed that about $80 \%$ of the hydrogen peroxide formed by BSAO cross the cell membrane of LoVo cells, and the uptake reached a maximum about 10 min after the enzymatic reaction was started (13). This observation also supports strongly the release of the toxic metabolites of spermine by BSAO near the cell surface.

According to Sharmin et al (36) acrolein is the actual toxic metabolite of spermine. However, acrolein is formed by spontaneous B-elimination from the aldehydes that are formed by BSAO-catalyzed oxidative deamination $(10,11,45)$.

The rate of B-elimination is dependent on environmental conditions, and it is unknown under most experimental settings. In view of our lacking knowledge of the composition of the aldehyde mixture formed from spermine under our experimental conditions, it seemed justified to use acrolein as the model compound.

Particularly interesting and promising is the finding that M14 ADR2 cells were much more sensitive to the toxic metabolites of spermine than their wild-type counterpart (Fig. 4e and f).
From a therapeutic point of view, the improvement of the efficacy of in situ formation of the cytotoxic oxidation products of spermine is fundamental. This may be performed by association of the treatment with, for example, lysosomotropic compounds that improve cell damage by spermine metabolites. In the present study, emphasis was put on the ability of MDL 72527 to sensitize melanoma cells to $\mathrm{H}_{2} \mathrm{O}_{2}$ and aldehyde formed from $\mathrm{BSAO} /$ spermine enzymatic system treatment.

The ultrastructural alterations of M14 cells observed after exposure to MDL 72527 alone, or in combination with BSAO and spermine, are similar to those observed previously in LoVo cells $(10,43)$. In essence, they support the view that MDL 72527 acts as a lysosomotropic compound, as was reported by Dai et al (46) for leukemia cells, and that the sensitization of M14 melanoma cells to the treatment with BSAO and spermine is mainly due to the effects induced by pre-treatment with MDL 72527 on the endosomal-lysosomal system. Among the ultrastructural changes produced by MDL 72527, the rapid formation of cytoplasmic vacuoles was the most striking. Laser scanning confocal microscopic observations and flow cytometric quantitative analysis (Figs. 8 and 9), by using acridine orange staining, evidenced that these vacuoles were of lysosomal origin. In fact, such analysis showed that the treatment of both M14 WT and M14 ADR2 cells with MDL 72527 increased the number of lysosomal structures when compared to the respective controls. However, in contrast with the vacuoles formed in other cell lines, such as leukemia (46) and colon carcinoma cells (47), the vacuoles in melanoma M14 cells (11) and in adenocarcinoma LoVo cells (10), did not coalesce to form larger ones with time, but disappeared nearly completely in the presence of MDL 72527 at $48 \mathrm{~h}$ of incubation. Nevertheless, the findings suggest that vacuole formation did not correlate directly with the loss of cell viability. Instead, the ultrastructural alterations observed in mitochondria appear to correlate better with the cytotoxic effects induced by $\mathrm{BSAO} /$ spermine treatment. In agreement with this finding is the fact that mitochondria-mediated toxic effects are among the early events $(13,48)$.

A major role of lysosomes in cell death is presently not doubted $(49,50)$, and it is known that the release of lysosomal enzymes causes oxidative stress (51-53). The amplification of oxidative stress by the subsequent exposure of cells to hydrogen peroxide, and the toxic effects of the highly reactive spermine-derived aldehydes, explain the increase of cytotoxicity observed in cell survival experiments.

As shown in Fig. 5, MDL 72527 alone had no significant effect on cell viability even at $300 \mu \mathrm{M}$ concentration, but if followed by treatment with BSAO and spermine, cell viability decreased considerably. For this reason we consider the effect of MDL 72527 as a sensitization of the cells. In our opinion the release of lysosomal cathepsins is the major reason for the sensitizing effect, and we expect, therefore, that other lysosomotropic compounds affect cells similarly. In agreement with this suggestion, Zamorra and Beck (54) reported the enhancement of vincristine cytotoxicity by chloroquine to MDR leukemia cell line; while Ostenfeld et al (53) described that the agent siramesine, a compound with lysosomotropic properties, causes lysosomal leakage and cathepsin-dependent death of cancer cells in vitro 
and exhibits potent anti-cancer activity in vivo. Therefore, an important role of lysosomes in both necrotic and apoptotic cell death is well founded (49). In this connection it is of interest to note that hydrogen peroxide cytotoxicity has been reported to be preceded by a damage of lysosomal membranes (55). Owing to its lysosomotropic effect, pre-treatment with MDL 72527 amplifies the ability of the metabolites formed from spermine by oxidative deamination to induce cell death.

The exposure of phosphatidylserine, a negative charged phospholipid, on the outer surface of the cytoplasmic membrane clearly showed the onset of the apoptotic process. Flow cytometric analysis was performed by Annexin V-FITC assay (Fig. 10). The measurement of Annexin V binding, executed simultaneously with the exclusion dye PI, provided a suitable assay to detect apoptotic cells and to discriminate between apoptosis (both early and late) and necrosis. The cytotoxic spermine metabolites induced a significant increase of early apoptotic fraction on both cell lines $(22.8 \%$ in M14 WT and $17.6 \%$ in M14 ADR2 cells when compared to $3.2 \%$ and $1.9 \%$ in the respective control cells). The percentage of Annexin V positive cells in the sensitive M14 WT cell line was slightly higher than that in M14 ADR2 one, most probably because the MDR melanoma is also apoptosis-resistant (56). Pretreatment with MDL 72527 increased the percentage of apoptotic cells on both lines, but particularly on MDR cells, where it approximately doubled (42.8\%).

A further investigation on the cell cycle analysis by flow cytometry, revealed that sub-G1 hypodiploid cells, a marker of cell death by apoptosis, accumulated in response to the treatment of M14 WT and ADR2 cells with BSAO and spermine $6 \mu \mathrm{M}$ or when both cells lines were pre-treated with MDL 72527 and then treated with BSAO/spermine enzymatic system. Again, sub-G1 hypodiploid cells, a subpopulation of apoptotic cells with fragmented DNA, were only observed after incubation with BSAO and spermine or with the combined treatment. The increase of the peak sub-G1, induced by oxidation products of spermine, resulted much higher in M14 ADR2 cells ( 4 times) than in M14 WT ones after the combined treatment.

It is noteworthy, that some populations of M14 ADR2 cells were arrested at $\mathrm{G} 2 / \mathrm{M}$ phase after the combined treatment. This finding suggested the growth inhibitory effect of MDL 72527 associated at BSAO/spermine might be initiated from the cell cycle arrest at the G2/M phase before the MDR cells undergo apoptosis. The severe changes of the mitochondrial structure, such as dilatation of the cristae, disruption of membranes and chromatin condensation produced the characteristic apoptotic phenotype, mainly observed in multidrug-resistant cells.

Taking into consideration the findings above described, the difference between MDR and WT cells in sensitivity to treatment with BSAO and spermine, particularly after sensitization with $300 \mu \mathrm{M}$ of MDL 72527 is so obvious that it needs to be explained. Several human MDR cell lines express P-gp, a membrane-bound transporter protein, which functions as energy-dependent pump capable of extruding drugs out of cells (57). However, P-gp-mediated excretion of the toxic products of spermine oxidation appears to play no, or only a minor role, because M14 ADR2 cells were not less, but significantly more sensitive to exposure to BSAO and spermine than M14 WT cells. The higher sensitivity to cytotoxic spermine derivatives of colon adenocarcinoma LoVo DX cells, as compared with WT cells, has previously been attributed to an earlier and higher mitochondrial membrane depolarisation, and a higher basal production of ROS that was not related to the glutathione content, because MDR and WT LoVo cells have the same glutathione pool $(13,48)$. At present no data exist to allow to draw the same conclusion on M14 melanoma cells, although the same physiological factors are possibly responsible for the enhanced sensitivity in both MDR cell lines.

To gain insight into the mechanism of chemosensitizing effect of MDL 72527, particularly on MDR cells, the effect of this pharmacological agent was analyzed and compared to that of the well-known P-gp substrate or inhibitor on the reactivity of MAb UIC2 against MDR variant of melanoma cells. In fact, it has been demonstrated that P-gp undergoes conformational changes during the phases of its energydependent drug pump activity (58), and such changes may determine epitope modulations with consequent variation of the immunoreactivity of specific anti-P-gp MAbs $(59,60)$. The modulation of the UIC2 epitope has been exclusively shown in the presence of P-gp substrates or ATP-depleting agents. In the present investigation, a positive correlation between MDL 72527 concentration and MAb UIC2 reactivity was found (Fig. 6). At the highest concentration $(300 \mu \mathrm{M})$, this compound induced the doubling of the UIC2 epitope expression, comparable to that determined after treatment with the well-known P-gp substrate, CsA. These results suggested that MDL 72527 is a substrate of P-gp; therefore, in this study $300 \mu \mathrm{M}$ of MDL 72527 was necessary for inducing a higher sensitization, than that caused by lower concentrations, on resistant melanoma cells to spermine metabolites.

Hydrogen peroxide formed by the xanthine oxidase reaction (61), as well as the products of BSAO-catalyzed oxidation of spermine, exhibit some anti-tumor properties in animal models (24). It was shown that spermine metabolites were more cytotoxic than equivalent concentrations of exogenous hydrogen peroxide and acrolein, suggesting that enzymatically produced metabolites have an advantage over the individual metabolites or their combination. Pretreatment with MDL 72527 sensitized the melanoma cells to the subsequent exposure to BSAO and spermine. Since this effect is in our opinion mainly the result of the lysosomotropy of MDL 72527, it is likely that lysosomotropic compounds will be found in the future, for which clinical experience exists (28). Our preliminary studies carried out on LoVo and M14 cells suggest that the anti-malarial drug chloroquine, an other lysosomotropic compounds, in association with $\mathrm{BSAO} /$ spermine, is also able to potentiate the cytotoxic effects of the enzymatic oxidation products of spermine (28). This compound synergises the cytotoxic effect of polyphenolic apple constituents, the procyanidins, and anthracyclines in metastatic colon carcinoma MDR and human leukemia cells (62).

In conclusion, the results herein described seem to suggest that lysosomotropic compounds, such as MDL 72527 and chloroquine, for their chemosensitizing properties might become of therapeutic importance as a new anti-tumoral 
approach. In particular, the combined action of MDL 72527 and $\mathrm{BSAO} /$ spermine system seems to represent a new and promising strategy against multidrug-resistant tumors.

\section{Acknowledgements}

This work was partially supported by the Ministero della Salute (1\% Fondo Sanitario Nazionale), the Italian MIUR (Ministero dell'Istruzione, dell'Università e della Ricerca) and by funds MIUR-PRIN (Cofin). Thanks are due to 'Fondazione Sovena' for the scholarship given to Nikenza Viceconte for supporting her Ph.D. MDL 72527 was a gift of Professors N. Seiler and F. Raul, University of Strasbourg.

\section{References}

1. Pegg AE: Recent advances in the biochemistry of polyamines in eukaryotes. Biochem J 234: 249-262, 1986.

2. Pegg AE: Polyamine metabolism and its importance in neoplastic growth and a target for chemotherapy. Cancer Res 48: 759-774, 1988.

3. Williams-Ashman HG and Canellakis ZN: Polyamines in mammalian biology and medicine. Perspect Biol Med 22: 421-453, 1979.

4. Tabor CW and Tabor H: Polyamines. Annu Rev Biochem 53: 749-790, 1984.

5. Casero RA Jr and Marton LJ: Targeting polyamine metabolism and function in cancer and other hyperproliferative diseases. Nat Rev Drug Discov 6: 373-390, 2007.

6. Pegg AE: Spermidine/spermine-N(1)-acetyltransferase: a key metabolic regulator. Am J Physiol Endocrinol Metab 294: E995-E1010, 2008.

7. Wallace HM and Fraser AV: Polyamines analogues as anticancer drugs. Biochem Soc Trans 31: 393-396, 2003.

8. Mondovì B, Riccio P, Agostinelli E and Marcozzi G: Oxidation of diamines and polyamines. In: The Physiology of Polyamines. Vol. 1. Bachrach U and Heimer YM (eds). CRC Press, Boca Raton, pp177-201, 1989.

9. Bachrach U: Polyamines as indicators of disease activity and response to therapy in cancer patients. In: The Physiology of Polyamines. Vol. 2. Bachrach U and Heimer YM (eds). CRC Press, Boca Raton, pp234-249, 1989.

10. Agostinelli E, Dalla Vedova L, Belli F, Condello M, Arancia G and Seiler N: Sensitization of human colon adenocarcinoma cells (LoVo) to reactive oxygen species by lysosomotropic compounds. Int J Oncol 29: 947-955, 2006.

11. Agostinelli E, Belli F, Molinari A, Condello M, Palmigiani P, Dalla Vedova L, Marra M, Seiler N and Arancia G: Toxicity of enzymatic oxidation products of spermine to human melanoma cells (M14): sensitization by heat and MDL 72527. Biochim Biophys Acta 1763: 1040-1050, 2006

12. Lindsay GS and Wallace HM: Changes in polyamine catabolism in HL-60 human promyelogenous leukaemic cells in response to etoposide-induced apoptosis. Biochem $\mathrm{J} 337$ : 83-87, 1999.

13. Calcabrini A, Arancia G, Marra M, Crateri P, Befani O Martone A and Agostinelli E: Enzymatic oxidation product of spermine induce greater cytotoxic effects on human multidrugresistant colon carcinoma cells (LoVo) than on their wild-type counterparts. Int J Cancer 99: 43-52, 2002.

14. Agostinelli E and Seiler N: Non-irradiation-derived reactive oxygen species (ROS) and cancer. Therapeutic implications. Amino Acids 31: 341-355, 2006.

15. Agostinelli E, Belli F, Dalla Vedova L, Marra M, Crateri P and Arancia G: Hyperthermia enhances cytotoxicity of amine oxidase and spermine on drug-resistant colon adenocarcinoma cells (LoVo). Int J Oncol 28: 1543-1553, 2006.

16. Seiler N: Thirty years of polyamine-related approaches to cancer therapy. Retrospect and prospect. Part 1. Selective enzyme inhibitors. Curr Drug Targets 4: 537-564, 2003.

17. Seiler N: Thirty years of polyamine-related approaches to cancer therapy. Retrospect and prospect. Part 2. Structural analogues and derivatives. Curr Drug Targets 4: 565-585, 2003.

18. Bachrach U: Polyamines and cancer: minireview article. Amino Acids 26: 307-309, 2004
19. Gerner EW, Meyskens FL Jr, Goldschmid S, Lance P and Pelot D: Rationale for, and design of, a clinical trial targeting polyamine metabolism for colon cancer chemoprevention. Amino Acids 33: 189-195, 2007.

20. Jiang R, Choi W, Khan A, Hess K, Gerner EW, Casero RA Jr, Yung WK, Hamilton SR and Zhang W: Activation of polyamine catabolism by $\mathrm{N}^{1}, \mathrm{~N}^{11}$-diethylnorspermine leads to cell death in glioblastoma. Int J Oncol 31: 431-440, 2007.

21. Simoneau AR, Gerner EW, Nagle R, Ziogas A, FujikawaBrooks S, Yerushalmi H, Halering TE, Liebermann R, McLaren CE, Anton-Culver H and Meyskens FL Jr: The effect of difluoromethylornithine on decreasing prostate size and polyamines in men: results of a year-long phase IIb randomized placebo-controlled chemoprevention trial. Cancer Epidemiol Biomarkers Prev 17: 292-299, 2008.

22. Agostinelli E, Arancia G, Dalla Vedova L, Belli F, Marra M, Salvi $\mathrm{M}$ and Toninello A: The biological function of polyamine oxidation products by amine oxidases: perspectives of clinical applications. Amino Acids 2: 347-358, 2004.

23. Agostinelli E, Tempera G, Molinari A, Salvi M, Battaglia V, Toninello A and Arancia G: The physiological role of biogenic amines redox reactions in mitochondria. New perspectives in cancer therapy. Amino Acids 33: 175-187, 2007.

24. Averill-Bates DA, Cherif A, Agostinelli E, Tanel A and Fortier G: Anti-tumoral effect of native and immobilized bovine serum amine oxidase in a mouse melanoma model. Biochem Pharmacol 69: 1693-1704, 2005.

25. Averill-Bates DA, Ke Q, Tanel A, Roy J, Fortier G and Agostinelli E: Mechanism of cell death induced by spermine and amine oxidase in mouse melanoma cells. Int J Oncol 32: 79-88, 2008.

26. Marra M, Agostinelli E, Tempera G, Lombardi A, Meo G, Budillon A, Abbruzzese A and Caraglia M: Anticancer drugs and hyperthermia enhance cytotoxicity induced by polyamine enzymatic oxidation products. Amino Acids 33: 273-281, 2007.

27. Marra M, Lombardi A, Agostinelli E, Giuberti G, Zappavigna S, Tempera G, Vitale G, Bifulco M, Abbruzzese A and Caraglia M: Bovine serum amine oxidase and spm potentiate docetaxel and interferon-alpha effects in inducing apoptosis on human cancer cells through the generation of oxidative stress. BBA-Mol Cell Res 1783: 2269-2278, 2008.

28. Agostinelli E and Seiler N: Lysosomotropic compounds and spermine enzymatic oxidation products in cancer therapy (review). Int J Oncol 31: 473-484, 2007.

29. Bey P, Bolkenius FM, Seiler N and Casara P: N-2,3-Butadienyl1,4-butanediamine derivatives. Potent irreversible inhibitors of mammalian polyamine oxidase. J Med Chem 28: 1-2, 1985.

30. Turini P, Sabatini S, Befani O, Chimenti F, Casanova C, Riccio $\mathrm{P}$ and Mondovì $\mathrm{B}$ : Purification of serum amine oxidase. Anal Biochem 125: 294-298, 1982.

31. Janes SM, Mu D, Wemmer D, Smith AJ, Kaur S, Maltby D, Burlingame AL and Klinman JP: A new redox cofactor in eukaryotic enzymes: 6-hydroxydopa at the active site of bovine serum amine oxidase. Science 248: 981-987, 1990.

32. Molinari A, Toccaceli L, Calcabrini A, Diociaiuti M, Cianfriglia $\mathrm{M}$ and Arancia G: Induction of P-glycoprotein expression on the plasma membrane of human melanoma cells. Anticancer Res 20: 2691-2696, 2000.

33. Molinari A, Calcabrini A, Crateri P and Arancia G: Interaction of anthracyclin with cytoskeletal components of cultured carcinoma cells (CG5). Exp Mol Pathol 53: 11-33, 1990.

34. Van Engeland M, Nieland LJ, Ramaekers FC, Schutte B and Reutelingsperger CP: Annexin V-affinity assay: a review on an apoptosis detection system based on phosphatidylserine exposure. Cytometry 31: 1-9, 1998.

35. Nicoletti I, Migliorati G, Pagliacci MC, Grignani F and Riccardi C: A rapid and simple method for measuring thymocyte apoptosis by propidium iodide staining and flow cytometry. J Immunol Methods 139: 271-279, 1991.

36. Sharmin S, Sakata K, Kashiwagi K, Ueda S, Iwasaki S, Shirahata A and Igarashi K: Polyamine cytotoxicity in the presence of bovine serum amine oxidase. Biochem Biophys Res Commun 282: 228-235, 2001.

37. Seiler N, Duranton B and Raul F: The polyamine oxidase inactivator MDL 72527. Prog Drug Res 59: 1-40, 2002.

38. Vermes I, Haanen C, Steffens-Nakken H and Reutelingsperger C: A novel assay for apoptosis. Flow cytometric detection of phosphatidylserine expression on early apoptotic cells using fluorescein labelled Annexin V. J Immunol Methods 184: 39-51, 1995. 
39. Goodwin AC, Jadallah S, Toubaji A, Lecksell K, Hicks JL, Kowalski J, Bova GS, De Marzo AM, Netto GJ and Casero RA Jr: Increased spermine oxidase expression in human prostate cancer and prostatic intraepithelial neoplasia tissues. Prostate 68: 766-772, 2008.

40. Agostinelli E, Przybytkowskj E, Mondovì B and AverillBates DA: Heat enhancement of cytotoxicity induced by oxidation products of spermine in Chinese hamster ovary cells. Biochem Pharm 72: 36-42, 1994.

41. Demers N, Agostinelli E, Averill-Bates DA and Fortier G: Immobilization of native and poly(ethylene glycol)-treated (PEGylated) bovine serum amine oxidase into a biocompatible hydrogel. Biotech Appl Biochem 33: 201-207, 2001.

42. Heby O and Persson L: Molecular genetics of polyamine synthesis in eukaryotic cells. Trends Biochem Sci 15: 153-158, 1990.

43. Agostinelli E, Tempera G, Dalla Vedova L, Condello M and Arancia G: MDL 72527 and spermine oxidation products induce a lysosomotropic effect and mithocondrial alterations in tumour effect. Biochem Society Trans 35: 343-348, 2007.

44. Dini L, Agostinelli E and Mondovi B: Cultured hepatocytes bind and internalize bovine serum amine oxidase-gold complex. Biochem Biophys Res Commun 179: 1169-1174, 1991.

45. Averill-Bates DA, Agostinelli E, Przybytkowskj E and Mondovì B: Aldehyde dehydrogenase and cytotoxicity of purified bovine serum amine oxidase and spermine in Chinese hamster ovary cells. Biochem Cell Biol 72: 36-42, 1994.

46. Dai H, Kramer DL, Yang C, Murti KG, Porter CW and Cleveland JL: The polyamine oxidase inactivator MDL-72527 selectively induces apoptosis in transformed hematopoietic cells through lysosomotropic effects. Cancer Res 59: 4944-4954, 1999.

47. Duranton B, Holl V, Schneider Y, Carnesecchi S, Gosse F, Raul F and Seiler N: Cytotoxic effects of the polyamine oxidase inactivator MDL 72527 to two human colon carcinoma cell lines SW 480 and SW 629. Cell Biol Toxicol 18: 381-396, 2002.

48. Arancia G, Calcabrini A, Marra M, Crateri P, Artico M, Martone A, Martelli F and Agostinelli E: Mitochondrial alterations induced by serum amine oxidase and spermine on human multidrug resistant tumor cells. Amino Acids 26: 273-282, 2004.

49. Guicciardi ME, Leist M and Gores GJ: Lysosomes in cell death. Oncogene 23: 2881-2890, 2004.
50. Kroemer G and Jäättelä M: Lysosomes and autophagy in cell death control. Nat Rev Cancer 5: 886-897, 2005.

51. Zhao M, Antunes F, Eaton JW and Brunk UT: Lysosomal enzymes promote mitochondrial oxidant production, cytochrome c release and apoptosis. Eur J Biochem 270: 13778-13786, 2003.

52. Yu Z, Li W and Brunk UT: 3-Aminopropanal is a lysosomotropic aldehyde that causes oxidative stress and apoptosis by rupturing lysosomes. APMIS 111: 643-652, 2003.

53. Ostenfeld MS, Høyer-Hansen M, Bastholm L, Fehrenbacher N, Olsen OD, Groth-Pedersen L, Puustinen P, KirkegaardSørensen T, Nylansted J, Farkas T and Jäättelä M: Anti-cancer agent siramesine is a lysosomotropic detergent that induces cytoprotective autophagosome accumulation. Authophagy 4: 487-499, 2008

54. Zamorra JM and Beck WT: Chloroquine enhancement of anticancer drug cytotoxicity in multidrug resistant human leukemic cells. Biochem Pharmacol 35: 4303-4310, 1986.

55. Zdolsek J, Zhang H, Roberg $\mathrm{K}$ and Brunk U: $\mathrm{H}_{2} \mathrm{O}_{2}$-mediated damage to lysosomal membranes of J-774 cells. Free Radic Res Commun 18: 171-185, 1993.

56. La Porta CA: Drug resistance in melanoma: new perspectives. Curr Med Chem 14: 387-391, 2007.

57. Gottesman MM and Pastan I: Biochemistry of multidrug resistance mediated by the multidrug transporter. Annu Rev Biochem 62: 385-427, 1993.

58. Ambudkar SV, Kimchi-Sarfaty C, Sauna ZE and Gottesman MM: P-glycoprotein: from genomics to mechanism. Oncogene 22: 7468-7485, 2003.

59. Mechetner EB and Roninson IB: Efficient inhibition of the Pglycoprotein-mediated multidrug resistance with a monoclonal antibody. Proc Natl Acad Sci USA 89: 5824-5828, 1992.

60. Mechetner EB, Schott B, Morse BS, Stein WD, Druley T, Davis KA, Tsuruo T and Roninson IB: P-glycoprotein function involves conformational transitions detectable by differential immunoreactivity. Proc Natl Acad Sci USA 94: 12908-12913, 1997.

61. Yoshikawa T, Kokura S, Tainaka K, Naito Y and Kondo M: A novel cancer therapy based on oxygen radicals. Cancer Res 55: 1617-1620, 1995

62. Seiler N, Chaabi M, Roussi S, Gosse F, Lobstein A and Raul F: Synergism between apple procyanidins and lysosomotropic drugs: potential in chemoprevention. Anticancer Res 26: 3381-3385, 2006. 